\title{
Water Filtration of the Forearm in Short- and Long-Term Diabetes Mellitus
}

\author{
H. L. Poulsen and S. L. Nielsen \\ Department of Clinical Physiology, Bispebjerg Hospital and Steno Memorial Hospital, Gentofte, Copenhagen, Denmark
}

\begin{abstract}
Summary. Blood flow and capillary filtration coefficient (CFC) were measured by strain-gauge plethysmography on the upper and lower third of the forearm in 9 normal subjects and 29 well regulated patients with diabetes mellitus of varying duration (less than 10 years, 10 to 20 years, and more than 20 years). There was no difference in blood flow in the four groups, but CFC was significantly increased in longterm diabetics (duration above 20 years) when measured at the distal part of the forearm near the wrist. Calculations showed that this was probably due to the relatively high contribution of connective tissue in this part of the forearm. Increased water filtration in connective tissue in long-term diabetics is in accordance with earlier findings of a lowered subcutaneous interstitial fluid albumin concentration in long-term diabetics, this being explained by an increase in net water outflux from the microcirculation.
\end{abstract}

Key words: Capillary filtration coefficient, capillary permeability, diabetes mellitus, forearm blood flow, lymph flow, muscle tissue, strain-gauge plethysmography, subcutaneous tissue.

In patients with long-term diabetes mellitus complicated with microangiopathy an increased capillary diffusion capacity (CDC) for smaller hydrophilic molecules. in skeletal muscles has been found [13]. Concerning macromolecules an increased transvascular escape rate of intravenously injected albumin was found in a similar group of patients [10]. This points to a generally elevated vascular permeability in diabetic subjects with microangiopathy. Surprisingly, we recently demonstrated that the interstitial fluid albumin concentration in the subcutaneous tissue of the forearm of long-term juvenile diabetics was significantly lower than in normal subjects [11]. A possible explanation for this is, that the net transvascular water transport is increased in long-term diabetics, this transport being even more increased than the transvascular albumin transport.

The aim of the present study was to examine whether increased microvascular water permeability could be demonstrated in the forearm of long-term diabetics. An attempt was made to estimate the importance of the tissue composition for the CFC by performing simultaneous measurement of capillary filtration coefficient (CFC) in two segments of the forearm, viz. on the proximal and distal third, areas with different ratios between superficial connective tissue and deep muscle tissue. Our study thus extends the studies of Alpert et al. [1], who have reported a small but statistically insignificant increase of CFC, measured in the calf, in their diabetic subjects.

\section{Material and Methods}

Twenty nine juvenile diabetic subjects with varying duration of the disease were studied. They were all insulin dependent and in good metabolic state (blood sugar below $8 \mathrm{mmol} / \mathrm{l}$, without urinary ketosis at the investigation and with an urinary glucose excretion below $5 \mathrm{~g} /$ day 3 days prior to the investigation). They were divided in three groups with duration of disease below 10 years (short-term), between 10 and 20 years (medium-term) and above 20 years (long-term). The clinical data of the patients are shown in Table 1. Diagnostic criteria for microangiopathy were the following: Nephropathy is based on albuminuria (positive albustix ${ }^{\circledR}$ ), neuropathy on decrease in vibration sensibility and abnormal tendon reflexes in the lower 
Table 1. Clinical data for the diabetic subjects

\begin{tabular}{|c|c|c|c|c|c|c|c|c|c|c|c|}
\hline \multirow[t]{2}{*}{ Groups } & \multirow[t]{2}{*}{ No } & \multicolumn{2}{|c|}{ Sex } & \multirow{2}{*}{$\begin{array}{l}\text { Age } \\
\text { (years) }\end{array}$} & \multirow{2}{*}{$\begin{array}{l}\text { Duration of } \\
\text { diabetes } \\
\text { (years) }\end{array}$} & \multirow{2}{*}{$\begin{array}{l}\text { Retino- } \\
\text { pathy }\end{array}$} & \multirow{2}{*}{$\begin{array}{l}\text { Nephro- } \\
\text { pathy }\end{array}$} & \multirow{2}{*}{$\begin{array}{l}\text { Neuro- } \\
\text { pathy }\end{array}$} & \multirow{2}{*}{$\begin{array}{l}\text { Blood pressure } \\
(\mathrm{mm} \mathrm{Hg})\end{array}$} & \multicolumn{2}{|c|}{$\begin{array}{l}\text { Circumference } \\
\text { of forearm }(\mathrm{cm})\end{array}$} \\
\hline & & $\mathrm{M}$ & $F$ & & & & & & & prox. & dist. \\
\hline Non-diabetes & 9 & 5 & 4 & $\begin{array}{l}32 \pm 8^{a} \\
(20-42)^{b}\end{array}$ & - & - & - & - & $\begin{array}{l}123 / 75 \pm 12 / 12 \\
(110-144 / 65-100)\end{array}$ & $26 \pm 2$ & $17 \pm 1$ \\
\hline $\begin{array}{l}\text { Diabetes } \\
0-10 \text { years }\end{array}$ & 8 & 4 & 4 & $\begin{array}{l}24 \pm 7 \\
(16-32)\end{array}$ & $\begin{array}{l}4 \pm 2 \\
(1-8)\end{array}$ & 0 & 0 & 0 & $\begin{array}{l}119 / 80 \pm 11 / 7 \\
(110-140 / 70-90)\end{array}$ & $25 \pm 2$ & $17 \pm 2$ \\
\hline $10-20$ years & 9 & 5 & 4 & $\begin{array}{l}34 \pm 12 \\
(17-50)\end{array}$ & $\begin{array}{l}16 \pm 1 \\
(14-18)\end{array}$ & 7 & 3 & 6 & $\begin{array}{l}122 / 79 \pm 19 / 11 \\
(100-158 / 65-95)\end{array}$ & $24 \pm 2$ & $17 \pm 1$ \\
\hline$>20$ years & 12 & 8 & 4 & $\begin{array}{l}44 \pm 9 \\
(32-59)\end{array}$ & $\begin{array}{l}29 \pm 6 \\
(23-38)\end{array}$ & 11 & 4 & 9 & $\begin{array}{l}139 / 85 \pm 19 / 9 \\
(115-168 / 70-100)\end{array}$ & $24 \pm 2$ & $17 \pm 2$ \\
\hline
\end{tabular}

a Mean \pm S. D.

b Range

Table 2. Average resting blood flows and capillary filtration coefficients (CFC) $(\bar{x} \pm S . D$.) on the proximal and distal third of the forearm in normals and juvenile diabetics

\begin{tabular}{|c|c|c|c|c|c|c|}
\hline \multirow[t]{2}{*}{ Groups } & \multicolumn{2}{|l|}{ Flow } & \multicolumn{2}{|l|}{ CFC } & \multirow{2}{*}{$\begin{array}{l}\text { CFC prox./ } \\
\text { CFC dist. }\end{array}$} & \multirow{2}{*}{$\begin{array}{l}\text { CFC 3-5, prox./ } \\
\text { CFC 5-10, prox. }\end{array}$} \\
\hline & $\begin{array}{l}\text { Proximal } \\
(\mathrm{ml} / 100 \mathrm{ml} \cdot \mathrm{min})\end{array}$ & Distal & $\begin{array}{l}\text { Proximal } \\
{[\mathrm{ml} /(100 \mathrm{ml} \cdot \min }\end{array}$ & $\begin{array}{l}\text { Distal } \\
\mathrm{mm} \mathrm{Hg})] 10^{3}\end{array}$ & & \\
\hline $\begin{array}{l}\text { Normals } \\
\mathrm{n}=9 \\
\text { Diabetics }\end{array}$ & $2.37 \pm 1.85$ & $2.94 \pm 3.11$ & $2.02 \pm 0.76$ & $1.51 \pm 0.73$ & $1.50 \pm 0.68$ & $1.70 \pm 0.40$ \\
\hline $\begin{array}{l}0-10 \text { years } \\
n=8\end{array}$ & $2.02 \pm 0.75$ & $1.95 \pm 0.73$ & $1.75 \pm 0.59$ & $1.38 \pm 0.66$ & $1.44 \pm 0.48$ & $1.40 \pm 0.35$ \\
\hline $\begin{array}{l}10-20 \text { years } \\
n=9\end{array}$ & $2.01 \pm 0.54$ & $2.48 \pm 1.42$ & $2.03 \pm 0.42$ & $1.60 \pm 0.61$ & $1.33 \pm 0.38$ & $1.35 \pm 0.46$ \\
\hline $\begin{array}{l}>20 \text { years } \\
\mathrm{n}=12\end{array}$ & $2.92 \pm 1.38$ & $2.95 \pm 1.74$ & $2.34 \pm 0.94$ & $2.03^{a} \pm 0.58$ & $1.17 \pm 0.38$ & $1.12^{\mathrm{b}} \pm 0.14$ \\
\hline
\end{tabular}

a Denote significant increase from normal group $(\mathrm{p}<0.05)$

b Denote significant decrease from normal group $(p<0.05)$

extremities. Of the patients with retinopathy two in both the medium-term and long-term diabetic group had proliferative retinopathy, two in each of these groups had only microaneurysms, while the remaining patients in addition had exudates and haemorrhages. As a control group were 9 healthy non-hospitalized subjects without any family history of diabetes mellitus and with age comparable to the medium-term diabetic group.

All the investigations were carried out in the supine position after half an hour's rest at a room temperature of about $22^{\circ} \mathrm{C}$. Mercury-in-rubber strain-gauges (Parks Electronics, Mass., USA) were encircling the thickest part of the upper third of the forearm and the wrist and were attached by adhesive tape when stretched some $15 \%$. Two cuffs were placed just proximal and distal to the gauges. During measurements of blood flow and CFC the distal cuff was inflated to $50 \mathrm{~mm} \mathrm{Hg}$ to avoid displacement of blood from the hand.

Two identical series of measurements were performed with an interval of 15-30 min and average values were used for calculations. Five recordings of blood flow were made with a pressure of $50 \mathrm{~mm} \mathrm{Hg}$ in the proximal cuff and this was followed by recording of the volume-increase during $10 \mathrm{~min}$ of venous stasis using a pressure of $50 \mathrm{~mm} \mathrm{Hg}$. Transformation of electrical signal to increase in forearm volume was made by electric calibration. Blood flow was calculated as usual. Capillary filtration coefficient (CFC) was determined from the volume increase during the last $5 \mathrm{~min}$ of the stasis period and was expressed in $\mathrm{ml} /(100 \mathrm{ml}$ forearm $\cdot \mathrm{min} \cdot \mathrm{mm} \mathrm{Hg})$ without correction for transmission loss of pressure from cuff to exchange vessels.

Calculation of the volume increase during the ve- 
nous stasis was performed in more time periods $(0-1,1-2,2-3,3-5$ and $5-10 \mathrm{~min}$ of venous stasis) to see if there were differences in rate of volume increase in the diabetic groups.

From the simultaneous CFC measurements on proximal and distal third of the forearm an estimate of CFC in skeletal muscle $\left(\mathrm{CFC}_{\mathrm{m}}\right)$ and superficial tissue $\left(\mathrm{CFC}_{\mathrm{s}}\right)$ was obtained from the tissue composition of the segments assuming bones and tendons to give no volume increase during prolonged venous stasis $\left(\mathrm{CFC}_{\text {"bone" }}=0\right)$. The percentage tissue composition of proximal and distal part of the forearm was obtained from Greenfield [4], assuming that the distal forearm had the same composition as the hand. This was in good accordance with planimetric measurements on topographic transverse section of these segments. The two equations for CFC-calculation were: $\mathrm{CFC}_{\text {prox }}=\mathrm{CFC}_{\mathrm{m}} \cdot 0.636+\mathrm{CFC}_{\mathrm{s}} \cdot 0.166+$ $\mathrm{CFC}_{\text {"bone" }} \cdot 0.198$

$\mathrm{CFC}_{\text {dist }}=\mathrm{CFC}_{\mathrm{m}}: 0.155+\mathrm{CFC}_{\mathrm{s}} \cdot 0.302+\mathrm{CFC}_{\text {"bone" }}$ $\cdot 0.543$

Statistical evaluation was performed with Student's $\mathrm{t}$-test for grouped samples.

\section{Results}

In Table 2 is shown mean blood flow values in the four groups determined before and between the two capillary filtration measurements. There were no significant differences in flow values, the normal and longterm diabetic group having essentially the same flows.

The measured capillary filtration coefficients from the proximal and distal third of the forearm (Table 2) showed a statistically significant increase in the distal part of the forearm in the diabetics with a duration of diabetes of more than 20 years. A similar trend, but not reaching statistical significance, was found in the proximal part.

The ratio between CFC measured proximally and distally on the forearm tended to give higher filtration in the distal part in long-term diabetics, but the difference was not significant (Table 2). It is often stated, that the volume increase during venous stasis is proportional with time from the third minute of stasis. As can be seen from the ratio between CFC measured in the $3-5$ and $5-10$ minutes period, there was a greater decrease in CFC with time in the normal group than in short-term and long-term diabetics (Table 2).

Table 3 shows estimated CFC values for muscle and superficial tissue calculated from the measured $\mathrm{CFC}$ values and the average tissue composition at the two segments of the forearm where strain-gauges were placed. CFC for muscle tissue in both the normal
Table 3. Average capillary filtration coefficients (CFC) of muscle and superficial tissue in normals and juvenile diabetics, calculated as described in text

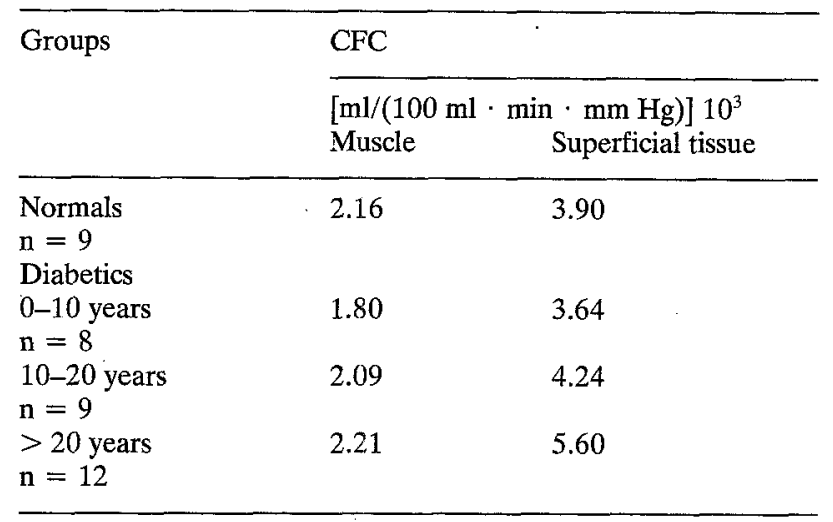

and diabetic groups was found to be about the same, $0.0020 \mathrm{ml} /(100 \mathrm{ml} \cdot \mathrm{min} \cdot \mathrm{mm} \mathrm{Hg})$. In all groups CFC in the loose connective tissue was about 2 times higher than CFC in deep tissues. The duration of the disease seemed to influence the CFC in superficial tissue increasing to $0.0056 \mathrm{ml} /(100 \mathrm{ml} \cdot \mathrm{min} \cdot \mathrm{mm} \mathrm{Hg})$ in the diabetics with duration of disease above 20 years. Statistical evaluation was not performed on the estimated CFC values because the estimate of tissue composition is based on few dissections [4].

\section{Discussion}

The application of venous stasis for measurement of capillary filtration of water in limb segments was described by Krogh et al. [8]. The principle has been extensively used studying changes in surface area for water exchange [2]. Few abnormalities have been found in this variable [7]. Recently Alpert et al. [1] found only a trend to increased water filtration in long-term diabetics, although this group showed a significantly increased extraction of smaller hydrophilic molecules, as previously found by Trap-Jensen and Lassen [13]. As noted by Thulesius [12], there seems to be an inconsistency in these findings since the filtrative transport of water and diffusive transport of smaller hydrophilic molecules are generally held to have the same pathway.

The most interesting finding in the present study therefore seems to be the significantly increased capillary filtration coefficient measured on the distal part of the forearm with a mercury-in-rubber strain-gauge in long-term diabetics having blood flow values identical with the normal group. If water filtration depends on surface area [2], then long-term diabetics should have a greater exchange area in contact with the flowing blood than normals. An increased surface area of 
this magnitude has been found in conjunctival vessels [3], but not in skeletal muscle [6] of long-term diabetics. However, studies of water permeability in the microcirculation with more accurate methods than the CFC method is necessary to elucidate the functional aspect of the histological observations. This has been performed on skeletal muscle in the human forearm using intraarterial infusion of hyperoncotic albumin solution to create water reabsorption [9]. This method showed a $40 \%$ increase in water permeability in skeletal muscle as compared to normals.

Compared to the study of Alpert et al. [1] two methodological changes were made in the present report. Firstly we made measurements on the forearm with more loose connective tissue than the calf, and secondly calculations were made on the filtration curves after $5 \mathrm{~min}$ of venous stasis, whereas Alpert et al. used the time interval from 3 to $5 \mathrm{~min}$. That venous stasis creates oedema located mainly in the loose tissue is well-known [5], but the advantage of simultaneous measurement on two regions of the same limb has never been used. We found that the ratio between proximal and distal CFC in the forearm had a tendency to decrease with the duration of diabetes (Table 2). From the rough estimates of mean composition of the forearm, it was possible to get an impression of the filtration in superficial and deep tissues. The relation between CFC in these tissues was similar to that reported in animal experiments where subcutaneous tissue has 2-3 times higher water filtration than skeletal muscle [14]. Our results suggested (Table 3 ) that the superficial tissues were mainly responsible for the increased filtration for water measured in long-term diabetics with the stasis technique. That CFC in skeletal muscle is increased, too, has been found by the whole forearm studies using an hyperoncotic bolus technique [9].

The impression gained from these data is, therefore, that the filtration permeability of the peripheral tissues is increased in long-term diabetics in agreement with the increased diffusion permeability to small molecules $[1,13]$. The findings are thus compatible with the idea that an increased net water filtration prevails in peripheral tissues in long-term diabetics, corresponding to an increased lymphatic return rate. This net water flux cannot be measured directly, and indirect measurements using albumin clearance from subcutaneous tissue have not been reported. One of the authors however, has found a significantly lower albumin concentration in subcutaneous tissue in longterm diabetic subjects than in normals [11], which may be accounted for by increased capillary water permeability and/or increased linear water velocity in the interstitial space in long-term diabetics. This indirectly supports the concept of increased net water filtra- tion in long-term diabetics, because this group also shows increased transvascular albumin escape from the intravascular space [10]. The concept accords with the clinical impression of enhanced tendency to development of peripheral oedema in such patients, even in cases with no gross nephropathy.

\section{References}

1. Alpert, J. S., Coffman, J. D., Balodimos, M. C., Koncz, L., Soeldner, J. S.: Capillary permeability and blood flow in skeletal muscle of patients with diabetes mellitus and genetic prediabetes. New Engl. J. Med. 286, 454 460 (1972)

2. Folkow, B., Mellander, S.: Measurements of capillary filtration coefficient and its use in studies of the control of capillary exchange. In: Capillary permeability (eds. C. Crone, N. A. Lassen), pp. 614-623. Copenhagen: Munksgaard 1970

3. Ditzel, J.: The conjunctival vessels in diabetes mellitus. Scand. Univ. Books. Copenhagen: Munksgaard 1962

4. Greenfield, A. D. M.: The circulation through the skin. In: Handbook of physiology (eds. W. F. Hamilton, P. Dow), pp. 1325-1351. Sect. 2, Circulation, Washington D. C.: Amer. Physiol. Soc. 1963

5. Hyman, C., Wong, W. H.: Capillary filtration coefficient in the extremities of man in high environmental temperatures. Circulat. Res. 22, 251-261 (1968)

6. Jacobsen, J. K., Trap-Jensen, J., Hansen, Aa. P., Nielsen, P. E., Reske Nielsen, E., Sander, E.: On permeability and morphology of skeletal muscle capillaries in diabetes mellitus. Acta endocr. scand. 181 (Suppl.), 3 (1974)

7. Kitchin, A. H.: Peripheral blood flow and capillary filtration rates. Brit, med. Buil. 19, 155-160 (1963)

8. Krogh, A., Landis, E. M., Turner, A. H.: The movement of fluid through the human capillary wall in relation to venous pressure and to the colloid osmotic pressure of the blood. J. clin. Invest. 11, 63-95 (1932)

9. Palm, T., Nielsen, S. L., Deckert, T.: Increased capillary filtration permeability to water in skeletal muscle of long-term diabetics measured by the osmotic transient method. (Submitted to Diabetologia)

10. Parving, H.-H., Rasmussen, S. M.: Transcapillary escape rate of albumin and plasma volume in short- and long-term juvenile diabetics. Scand. J. clin. Lab. Invest. 32, 81-87 (1973)

11. Poulsen, H. L.: Subcutaneous interstitial fluid albumin concentration in long-term diabetes mellitus. Scand. J, clin. Lab. Invest. 32, 167-173 (1973)

12. Thulesius, O.: Capillary filtration under normal and pathological conditions. Angiologica 10, 198-213 (1973)

13. Trap-Jensen, J., Lassen, N. A.: Increased capillary diffusion capacity for small ions in skeletal muscle in long-term diabetics. Scand. J. clin. Lab. Invest. 21, 116-122 (1968)

14. Oberg, B., Rosell, S.: Sympathetic control of consecutive vascular sections in canine subcutaneous adipose tissue. Acta physiol. scand. 71, 47-56 (1967)

Received: October 9, 1975, and in revised form: June 11, 1976

Dr. H. L. Poulsen

Dept. of Clinical Physiology

Bispebjerg Hospital

DK-2400 Copenhagen NV

Denmark 